\title{
Chaucer's Moon: Cintbia, Diana, Latona, Lucina, Proserpina
}

\section{JACQUELINE de WEEVER}

\begin{abstract}
Diana of the Romans and Artemis of the Greeks is the goddess of many names. In Hymn to Artemis, Callimachus (ca. 310 B.C.-235 B.C.) tells that, when she was a small child, Artemis requested from her father Zeus eternal girlhood, liberty, and many names. ${ }^{1}$ The most familiar of these are Cyntbia, Diana, Delia, Eileithyia, Hecate, Latona, Lucina, Luna, Phoebe, Proserpina, Selene, and Trivia. Ovid (43 B.C.-A.D.
\end{abstract}

1 Callimachus, Hymn to Artemis, 6-7, ed. and trans. A.W. Mair. Loeb Classical Library (London: W. Heinemann), 60 and 61. Mair translates the lines: "Give me to keep my maidenhood, Father, forever." I have chosen Charles Seltman's translation from The Twelve Olympians (New York: Thomas Y. Crowell, 1960), 135.

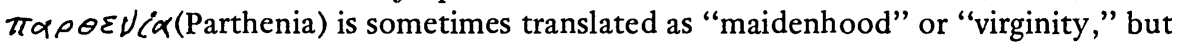
it is also an epithet of Hera, goddess of married women, Henry Stephen, Thesauraus Graecae Linguae (Paris: Firmin-Didot, 1842), column 509. The epithet is part of the evidence for syncretism between Artemis and Hera. Seltman's "girlhood liberty" seems more accurate in the light of other myths of the moon goddess. The myth of Endymion and the Moon contradicts the eternal maidenhood of the goddess, called Cyntbia by Martianus Capella, The Marriage of Pbilology and Mercury, IX, "Harmony," [919], Martianus Capella and the Seven Liberal Arts, trans. W.H. Stahl and Richard Johnson with E.L. Burge (New York: Columbia University Press, 1977), 2:255-256. Petrarch calls the moon Diana in his version, Africa, 1II.276-287. Trap orvos (Parthenos), usually translated "virgin," has been re-defined; classicists now say that it means not virgo intacta but simply "unmarried," W.K.C. Guthrie, The Greeks and their Gods (Boston: Beacon Press, 1950), 102, and H.J. Rose, A Handbook of Greek Mytbology, Including its Extension to Rome (New York: E.P. Dutton, 1959), 113-114. 
17) uses many of these throughout his Metamorphoses and Fasti, as does Claudian (b. ca. A.D. 365) in De Raptu Proserpinae. ${ }^{2}$ Medieval mythographers also use several names for the moon goddess. Isidore of Seville (sixth century) mentions seven in his Etymologiae: Diana, Latonia (daughter of Latona), Lucina, Luna, Proserpina, Plutonia (wife of Pluto), Trivia. $^{3}$ Remigius of Auxerre (ninth century) mentions four in Commentum in Martianum Capellam: Diana, Lucina, Luna, Proserpina. ${ }^{4}$ Pierre Bersuire (fourteenth century) uses Diana, Luna, Proserpina, and Hecate. ${ }^{5}$ Chaucer uses five names for the planetary goddess: Cinthia, Diana, Latona, Lucina, Proserpina. In his work, each name denotes a particular aspect of the goddess. There is the athlete in Diana the hunter-known from classical times-and in Cynthia the charioteer, perhaps borrowed from Fulgentius; Artemis, Selene, and Luna are the charioteers in classical literature. Chaucer also presents the highly-strung, aggrieved queen, Proserpina, showing the influence of Proserpina ferox of Claudian's De Raptu Proserpinae. Latona and Lucina denote the quieter and more remote aspects of the goddess. Scholars, rightly, are wont to look for the sources of Chaucer's ono-

2 The names in De Raptu Proserpinae are Delia, Diana, Latonia, Luna, Pboebe, Trivia. They are all translated Diana by Maurice Plautnauer, Claudian. Loeb Classical Library. 2 vols. (London: W. Heinemann, 1922). This does not indicate the range of names to the reader who does not read the Latin text. Annette H. Eaton discusses verbal borrowings but not the proper names, The Influence of Ovid on Claudian (Washington, D.C.: The Catholic University of America Press, 1943), 107-118.

${ }^{3}$ Isidorus Hispalensis, Etymologiarum sive Originun Libri $X X$, ed. W.M. Lindsay. 2 vols. (Oxford: Clarendon Press, 1911, reprint 1962), I:VIII.xi.56-57: “Dianam autem vocatem quasi Duanam, quod luna et die et nocte appareat. Ipsam et Lucinam adseverant, eo quod luceat. Eandem et Triviam, eo quod tribus fundatur figuris. De qua Vergilius (Aen. 4, 511):

Tria virginis ora Dianae, quia eadem Luna, eadem Diana, eadem Proserpina vocatur."

4 Remigius Autissiodorensis, Remigii Autissiodorensis Commentum in Martianum Capellam, VII, 369.1, ed. Cora E. Lutz (Leiden: E.J. Brill, 1962), 2:185: "Orgo Lucina dicitur in caelo, Diana in terris, Proserpina in inferno. Quaedam virgo Diana, Luna, et Proserpina."

${ }^{5}$ Petrus Berchorius, Reductorium Morale, Liber XV: Ovidius Moralizatus, Cap. I.: De Formis Figurisque Deorum, folio $6^{\mathrm{v}} \mathrm{a}-6^{\mathrm{v}} \mathrm{b}$. Ed. J. Engels (Utrecht: Instituut voor Laat Latijn der Rijksuniversiteit, 1966), 28. 
mastics and iconography in Petrarch, Bersuire, Dante, and Boccaccio, ${ }^{6}$ but many of his images have classical remnants which are either unrecognized or misunderstood. The image of the goddess of many names is complex and, often, contradictory; the virgin goddess who punishes pregnant nymphs is also patron of women in childbirth. Chaucer and the medieval mythographers inherited this complicated and, at times, confusing picture of the moon goddess from classical mythographers who seem to have accepted her many names and functions without question. A study of the names and the functions they denote may help the modern reader to understand the personalities of the women who invoke her and over whose lives she presides in Chaucer's poetry.

\section{Cintbia, Latona, Lucina}

Cintbia is derived from Cynthus, the mountain in Delos where Latona gave birth to Diana and Apollo. ${ }^{7}$ This name for the moon goddess appears twice in Troilus and Criseyde, only in connection with Criseyde. She begs Troilus not to mistrust her without cause, "for love of Cinthia the sheene," as she promises to return on the tenth day ( $T r$ IV.1607-1610). When Cynthia is racing her chariot across the heavens to reach the end of the sign Leo, at that very moment, instead of making her way back to Troy, Criseyde prepares for bed in her father's tent and decides to remain in the Greek camp. In one of the most beautiful stanzas in the poem, Chaucer states the time in an astronomical periphrasis: ${ }^{8}$

6 For example, studies on Venus. See Ernest H. Wilkins, "Descriptions of Pagan Divinities from Petrarch to Chaucer," Speculum 32 (1957): 511-522; John M. Steadman, "Venus' citole in Chaucer's Knight's Tale and Berchorius," Speculum 34 (1959): 620-624; Betty Nye Quinn, "Venus, Chaucer, and Peter Bersuire," Speculum 38 (1963): 479-480. See also Robert Hollander, Boccaccio's Two Venuses (New York: Columbia University Press, 1966). There is no similar debate on Diana.

7 Hyginus, Fabula 140, ed. and trans. Mary Grant (Lawrence, Kan.: University of Kansas Publications, 1960), 115-116. Delia is similarly derived from Delos, the island.

8 For a discussion of other astronomical periphrases, see Chauncey Wood, "Astrology as a Rhetorical Device," in his Chaucer and the Country of the Stars: Poetic Uses of Astrological Imagery (Princeton: 1970), 78-102. 
The brighte Venus folwede and ay taughte

The wey ther brode Phebus down alighte;

And Cynthea hire char-hors overraughte

To whirle out of the Leoun, if she myghte;

And Signifer his candels sheweth brighte,

Whan that Criseyde unto hire bedde wente

Inwith hire fadres faire brighte tente. ( $T r$ V.1016-1022)

Since the sun and the moon are in Leo, the moon is not visible, ${ }^{9}$ so Signifer, the zodiacal belt which carries the signs, shines brightly. Although the moon is invisible, the image of the charioteer is most vivid. In contrast, Criseyde does not take the action expected of her, the journey back to Troy. She has sworn by Cynthia that she will return, and the moon is apparently aiding her-the night is dark, perfect for her journey; there is no moonlight to reveal her to the sentries about the camp. However, unlike her active goddess, Criseyde is inactive. She fails to keep her promise and, in preparing for bed, she prepares to break Troilus's heart. ${ }^{10}$ Cynthia is the link between the promise made and the promise broken. The planetary goddess must hold to her course, and is thus constant in her inconstancy; she must appear as the new moon on the tenth day. In this way, Chaucer emphasized Criseyde's change of heart. The moon will appear on the tenth day, but Troilus's sweetheart will not.

Hamilton M. Smyser supposes that the image of the charioteer lashing her horses on is an adaptation of Ovid's Phaeton, for, he says, the whole stanza is contrary to Chaucer's other astronomical periphrases which are intellectual rather than pictorial. He suggests that, in being pictorial, the image comes from Dante; he quotes a stanza from Para-

9 Robert K. Root, ed., The Book of Troilus and Criseyde by Geoffrey Chaucer, (Princeton: 1926, 1954), "Notes," 547. All quotations of Chaucer's poetry are from F.N. Robinson, ed., The Works of Geoffrey Chaucer. 2nd. ed. (Boston: Houghton Mifflin, 1957).

10 Troilus and Criseyde consummate their love on a similar night. Pandarus plans the dinner party for a night when it will rain, "upon the chaungynge of the moone/Whan lightles is the world a nvyght or tweyne," $\operatorname{Tr}$ III.549-550. (This peculiar spelling of nvyght appears in Robinson's edition). The dinner party occurs on the night of the very first appearance of the new moon, $\operatorname{Tr}$ III.624; similarly, Troilus expects Criseyde at the very first appearance of the new moon, "whan thyne hornes newe gynnen sprynge." 
diso describing Beatrice's smile. ${ }^{11}$ This stanza is, however, static: for as long as the two children of Latona are held in balance, so long did Beatrice smile and keep silent. There is none of the movement of Chaucer's Cinthia, whirling out of the Lion, her horses "overraughte." The image has its own history and integrity, and the chariot is drawn sometimes by horses, sometimes by bulls, and sometimes by white stags. Originally, there were four horses in the moon's chariot as well as in the sun's. The earliest known large scale sculpture of the moon goddess as charioteer appears in the east pediment of the Parthenon, built 446-432 B.C. In the extreme left hand corner, the four horses of Helios emerge from the waves, while in the extreme right hand corner the four horses of Selene sink wearily below the horizon. The ribbons crossed over Selene's breasts indicate her role as charioteer. ${ }^{12}$ Luna is the Latin name for Selene, ${ }^{13}$ and Luna's chariot and horses appear in Ovid's Metamorphoses. ${ }^{14}$ Virgil speaks of Luna's twin-yoked steeds, "Biiugis...equos...Lunae." 5 On the other hand, Manilius mentions Delia's biga in Astronomica. ${ }^{16}$ The biga is the two-horsed chariot.

11 Hamilton M. Smyser, "A View of Chaucer's Astronomy," Speculum 45 (1970), 369-370.

12 Frank Brommer, The Sculptures of the Parthenon: Metopes, Frieze, Pediments, Cult Statue. Trans. from the German by Mary Whittall. Foreword by John Boardman (London: Thames and Hudson, 1979), plates 142 and 143. Brommer says that the Elgin horse in the British Museum is the only one in good shape. Three other horse heads belonging to the moon's chariot were found but were very badly mutilated. He publishes photographs of them in plate 144. H.J. Rose states that Selene drives a pair, not four, and mentions the Elgin horse, Handbook of Greek Mythology, 34. But Brommer's photographs are conclusive.

13 Rose, 34; Joseph Eddy Fontenrose, "Selene," Oxford Classical Dictionary (Oxford: Clarendon Press, 1970), 970-971.

14 Ovid, Metamorphoses, XV.790 and II.208, with an English translation by Frank Justus Miller. Loeb Classical Library. 2 vols. (Cambridge, Mass.: Harvard University Press, 1960), 2:420 and 421;1:74 and 75 .

15 Virgil, Culex, 283, with an English translation by H. Rushton Fairclough. Rev. ed. Loeb Classical Library (Cambridge, Mass.: Harvard University Press, 1934, reprint 1966), 2:392 and 393.

16 Manilius, Astronomica, I.669, with an English translation by G.P. Goold. Loeb Classical Library (Cambridge, Mass.: Harvard University Press, 1977), 56 and 57. For knowledge of Manilius in the tenth century, see D.B. Gain, "Gerbert and 
Statius, whose work Chaucer knew, mentions the biga Titanis, referring to Diana as the daughter of the Titaness, Latona. ${ }^{17}$ Cassiodorus, Boethius's fellow statesman at the court of Theodoric the Goth in the sixth century, points out that the two-horse chariot at the Roman Circus represents the course of the moon, the four-horse chariot race that of the sun. ${ }^{18}$ It is not clear just when the moon's chariot lost two horses, but the image of the biga lunae is well established by the first century of the Christian era.

Sometimes the chariot is drawn by bulls. Claudian says that Luna's bulls are given a magic herb in De Raptu Proserpinae, III.103. ${ }^{19}$ In astrology, Taurus is the exaltation of the Moon and the bull and its horns have always been associated with the planet. ${ }^{20}$ One Carolingian

Manilius," Latomus 29 (1970): 128-132. For English knowledge of Manilius, see M.L.W. Laistner, The Intellectual Heritage of the Early Middle Ages (Ithaca, New York: Cornell University Press, 1957), 81. The image is further explained by the fact of female charioteers in the Olympic Games. Pausanias tells that Cynisca, daughter of Archidamas, king of Sparta, passionately loved the Olympics and bred horses to race in them. She was the first woman to win an Olympic victory in the chariot races. Her victory was commemmorated in a pediment at Olympia which Pausanias describes in Descriptions of Greece, III.8. Trans. by Sir James George Frazer. 6 vols. (London: Macmillan, 1913), I:143. No connection may be made between Cynthia and Cynisca, alas!

17 Statius, Thebaid, I.336-340, with an English translation by J.H. Mozeley. Loeb Classical Library. 2 vols. (London: W. Heinemann, 1928), I:355 and 367: "Iamque per emoriti surgens confinia Phoebi/Titanis late, mundo subvecta silenti,/rorifera gelidum tenuaverat aera biga." My italics. For Chaucer and Statius, see Boyd A. Wise, The Influence of Statius upon Chaucer (Baltimore, Md.: Furst, 1911).

18 Flavius Magnus Aurelius Cassiodorus, Epistola, III.51, 32-33, in Cassiodori Senatoris Variae Epistolae, ed. Th. Mommsen (Berlin: Weidmannos, 1894), 105: "Biga quasi lunae, quadriga solis imitatione regerta est....Obeliscorum quoque prolixitates ad caeli altitudinem sublevantur; sed potio soli, inferior lunae dicatus est." For horse-loving Artemis, see Pindar, Olympian Ode, III.19.

19 Claudian, De Raptu Proserpinae, III.400-403, Loeb edition, II:374 and 375.

20 Ptolemy, Tetrabiblos, I.19, ed. and trans. F.E. Robbins. Loeb Classical Library (Cambridge, Mass.: Harvard University Press, 1971), 88 and 89. The exaltation of a planet is that sign of the zodiac in which the planet has its greatest power. The moon is $2^{\circ}$ in Taurus at noon on January's wedding day, MerchT IV (E), 1885-1889, an ill omen in this tale. 
ivory of the Crucifixion shows the quadriga solis in the upper left hand corner and the triga, the chariot drawn by three animals, of Proserpina in the upper right hand corner. The goddess in the cart wears the crescent like a crown, and her cart is drawn by three bulls, indicating that she is the goddess of the underworld. ${ }^{21}$

The stag is part of the iconography of Diana, and Callimachus says that her chariot is drawn by four horned deer. ${ }^{22}$ But the deerdrawn chariot seems not to have been popular in classical art and literature, perhaps because in real life horses and bulls make better chariot animals.

These examples show that the Middle Ages were familiar with the chariot of the moon as a separate icon. In none of them, however, is the moon called Cyntbia. Cynthia and her bull-drawn chariot appear in the Prologue of Fulgentius's Mythologies, in a stanza very similar to Chaucer's:

Earth's territory crossed, and the chill world

Warmed by the chariot-wheels, the charioteer

Loosed his fire-breathing horses, from their necks

Removed the golden reins. Phoebus unyokes

His steeds, as Cynthia prepares her team.

The brother tests the waters with his foot

Up whence his sister rose. With starry cloak

Binding the earth, night bids the sky to rest

On dewy wings, while all agleam the moon,

Its two-pronged diadem adorned with stars,

The twin-bulls yoked together, mounted up

The fresh laid sky,...23

21 Erwin Panofsky, Renaissance and Renascences in Western Art (New York: Harper and Row, 1972), fig. 20, shows a mixture of Christian and pagan symbols. Perhaps the goddess of the underworld is appropriate in a work depicting the death of Him who harrowed Hell. In addition, see E. Panofsky and F. Saxl, "Classical Mythology in Medieval Art," Metropolitan Museum Studies 4 (1932-33): 228-280. Isidore says that to the infernal gods [belongs] the triga because it hastens along the three ages of man: "Trigas diis inferis, quia is pertres aetates homines ad se rapit: id est per infantiam, iuventutem, atque senectam," Etymologiae, XVII. xxxvii,2, ed. W.M. Lindsay, 2.

22 Callimachus, Hymn to Artemis, 98-108, Loeb edition, 68-71.

23 Fulgentius, Mytbologies, Book I, Prologue, Fulgentius the Mythographer, trans. from the Latin with introduction by Leslie George Whitbread (Columbus, 
Chaucer's stanza is more compressed than Fulgentius's prolix lines, but in both Phoebus sets as Cynthia rises with her team. In Chaucer's stan$\mathrm{za}$, horses draw the chariot while bulls do so in Fulgentius's lines. In both, Cynthia is the charioteer, not Luna, or Delia, or the Titaness. D.W. Robertson, Jr., has remarked that "it is not difficult to find in [Chaucer's] descriptions obvious reflections of Fulgentius."2 4 Leslie George Whitbread challenges this statement, but points out several places in Chaucer's work which show Fulgentian influence, including astrological interpretations of the pagan gods. ${ }^{25}$ This stanza, it seems to me, shows the direct influence of Fulgentius; the energy is the same in both poets' work.

The examples listed above show no consistency in ancient sources in naming the charioteer. She may be Cyntbia, Delia, Luna, or Selene. Chaucer uses Cintbia only in connection with Criseyde, and the charioteer appears only in this stanza, an ironic comment which emphasizes that Criseyde is "slydyng of corage." Troilus remembers her oath when she does not appear; he thinks that he has miscounted the days, but he reminds himself that she did promise to return before the moon passed out of the Lion ( $\operatorname{Tr}$ V.1184-1190). Criseyde is not as daring as the goddess she has invoked.

Latona is the Latin name of the Greek Titaness Leto, daughter of Phoebe, "the bright one," mother of Diana and Apollo. She appears only once in Chaucer's works, in Troilus's prayer to the full moon as

Ohio: Ohio University Press, 1971), 46. Fulgentius may have been influenced by Statius since he knew the Thebaid and wrote a commentary on it, Super Thebaidem. For a discussion of manuscripts and Fulgentius's popularity, see M.L.W. Laistner, "Fulgentius in the Carolingian Age," in his The Intellectual Heritage of the Early Middle Ages, 202-211. For the influence of Fulgentius in the twelfth, thirteenth, and fourteenth centuries, see Whitbread, "Introduction," Fulgentius the Mythographer, 25-28. Petrarch, Bersuire, and Boccaccio named Fulgentius as one of their sources, Jean Seznec, The Survival of the Pagan Gods: The Mythological Tradition and Its Place in Renaissance Humanism and Art, trans. Barbara F. Sessions (New York: Pantheon Books, 1953), 173-175.

24 D.W. Robertson, Jr., A Preface to Chaucer: Studies in Medieval Perspectives (Princeton, 1970), 370.

25 Whitbread, Fulgentius the Mythographer, 28. 
he awaits Criseyde's return to Troy:

I saugh thyn hornes old ek by the morwe,

Whan hennes rood my righte lady dere,

That cause is of my torment and my sorwe;

For which, $\mathrm{O}$ brighte Latona the clere,

For love of God, ren faste about thy spere!

For whan thyne hornes newe gynnen sprynge,

Than shal she come that may my blisse brynge. ( $\operatorname{Tr}$ V.652-658)

Skeat, Robinson, and Baugh propose that Latona is a mistake here for Lucyna, either Chaucer's or the scribes', since all the manuscripts read Lat(b)ona. ${ }^{26}$ I suggest that there may be a medieval manuscript tradition for the error. Fulgentius says that Latona is called Luna (Exposition of the Content of Virgil, 24). ${ }^{27}$ As shown above, Luna is one of Diana's names. It has been shown that another Chaucerian mistake may have been a manuscript tradition, Marcia in the House of Fame III.1229. Alfred David has shown that there is a feminine Marsyas in one of the manuscripts of the Roman de la Rose. ${ }^{28}$ May this not be the case with Latona, that the error is, in fact, a manuscript tradition, that Chaucer may have learned Latona as a name for the moon from a manuscript of Ovid or Claudian? Two occurrences do not a tradition make, and the matter needs more investigation.

The stanza in the Troilus is a problematical one. If "thyn hornes olde" refer to the horns of the last quarter, then the time of the month should be the dark of the moon, and Troilus is awaiting the appear-

26 W.W. Skeat, ed., The Works of Geoffrey Chaucer. 2nd ed. 7 vols. (Oxford: Clarendon Press, 1900), 2:497; F.N. Robinson, "Explanatory Notes," 833; A.C. Baugh, Chaucer's Major Poetry (New York: Appleton Century Crofts, 1963), 192.

27 Fulgentius the Mythographer, 133. Latona as a name for the moon appears in Michael Drayton's "Endymion and Phoebe," 826, in The Works of Michael Drayton, ed. J. William Hebel. 5 vols. (Oxford: B. Blackwell, 1951), I:150. The note on this line reads: "Confusion between Latona and Lucina is already in Chaucer," $5: 22$. Whitbread also points out that Latona is an error, without further comment, 152.

28 Alfred David, "How Marcia Lost her Skin: A Note on Chaucer's Mythology," in The Learned and the Lewed: Studies in Chaurcer and Medieval Literature, ed. Larry D. Benson. Harvard English Studies, 5. (Cambridge, Mass.: Harvard University Press, 1974), 19-29. 
ance of the new moon. But he addresses "brighte Latona the clere"; Chaucer repeats "brighte" from the preceding stanza so that there is no mistake that the moon shines brightly. Then "thyn hornes olde" must refer to the last horns of the waxing moon, just before it becomes full. Not only do the new moon and the old moon have horns, however, but the full moon as well. Boethius says, Palleant plenae cornua lunae, in De Consolatione Philosopbiae IV, Metrum 5, which Chaucer translates: "the hornes of the full mone waxen pale." Thus the new moon, the full moon, and the old moon are all horned. It appears from the stanza quoted above that the moon was waxing when Criseyde left Troy with the Greeks; it is now full, and Troilus looks forward to her return when the horns of the new moon appear.

Chauncey Wood remarks that the repetition of borned and bornes in this and the preceding stanzas is doubtless ironic, given the outcome of the romance. ${ }^{29}$ The horns of the moon are a commonplace, and it is the female planet which is horned, not the male (the sun). ${ }^{30}$ It is a familiar image in classical art and literature. ${ }^{31}$ Claudian describes Proserpina's dress, embroidered with pictures of the birth of the sun and the moon, and the moon's forehead is marked with a little horn (De Raptu Proserpinae, II.36-54). Chaucer was thus familiar with the image from his reading of Boethius and Claudian. The horns of the cuckold cannot be pinned on Troilus, for he is not married to Criseyde, who is allied with the images of the moon in the romance. As Robin the Miller tells Oswald the Reeve, "Who hath no wyf, he is no cokewold," (KnT (A) 3152). The stanza gives voice to Troilus's longing for Criseyde, and the reader feels the pathos of the situation, knowing that Criseyde is unfaithful. Latona here is bright, yet remote, and cannot help Troilus, who appeals so yearningly to her.

Lucina, "she who brings the light," "the illuminator," derived from

29 Chauncey Wood, Chaucer and the Country of the Stars, 90.

30 Jane Ellen Harrison, Epilogomena to the Study of Greek Religion and Themis (Hyde Park, New York: University Books, 1962), 200, fig. 51. On the red-figure krater reproduced, Selene wears a cap with little horns as she stands in the quadriga solis.

31 Pausanius describes a stone image of the moon with horns in front, Descriptions of Greece, IV.xxiv.6, trans. Sir James G. Frazer, I:322. 
Latin Lux, lucis, is the Latin equivalent of Greek Eileitbyia, an epithet of Artemis. Diana Lucina presides over childbirth; a woman in labor appeals to her in one of the paintings on the walls of her oratory in the Knight's Tale, 2083-86. ${ }^{32}$ This is one of the contradictions in the character of Diana. The goddess can preside only over those functions she has herself experienced, ${ }^{33}$ and Diana is known to us chiefly as the chaste goddess. There is another side to her personality, typified in the many-breasted Artemis of Ephesus, which portrays her as Great Mother. ${ }^{34}$ Martianus Capella says that it is Cynthia who falls in love with Endymion, and Cynthia has been associated with the chaste goddess. ${ }^{35}$ From the love affair with Endymion, the moon goddess bore fifty daughters. The Great Mother and the chaste goddess seem to exist side by side in classical and medieval mythographers. Remigius of Auxerre knows a myth of a love affair between Diana and Jove, because of which Jove gave her the light and power to wax and wane. ${ }^{36}$ The combination of chastity and maternity, admittedly, is a confusing one, but Chaucer inherited it and this portrayal appears in the temple. Diana presides over childbirth because she was born painlessly to her mother Latona, and women prayed to Diana when in labor (Callimachus,

32 Lucina is also a byname for Juno, wife of Jupiter, suggesting the connection between Diana, Dione, and Juno, Ovid, Fasti, III.255-256. Trans. Sir James G. Frazer. Loeb Classical Library (Cambridge, Mass.: 1951, reprint 1967), 138 and 139. On these connections, see Frazer, "Appendix," 385-387. Juno and Diana are both goddesses of childbearing.

33 A full discussion of this subject belongs to anthropology and folklore. See Sir James G. Frazer, The Golden Bough: A Study in Magic and Religion. 3rd ed. 11 vols. (New York: Macmillan, 1935), 1 and 2.

34 W.K.C. Guthrie, The Greeks and their Gods, 100: "If Artemis protected the young of all species, including mankind, it was for a very good reason, namely, that she had originally been their mother."

35 Martianus Capella, The Marriage of Pbilology and Mercury, Book IX, "Harmony," [919]. See note 1 above.

36 Remigius Autissiodorensis, Commentum in Martianum Capellam, Liber IX. 484.7, ed. Cora Lutz, 2:315: "Iovis adamavit Dianam et cum ea concubit, praemiumque ei dedit potestam noctis lumenque eius auratis cornubus crescere et decrescere." 
Hymn to Artemis, 21-25). Thus the figure of Diana is composed of many layers.

Lucina as planet controls the tides, a function given powerful description in The Franklin's Tale. Aurelius prays Phoebus to ask his sister Lucina the sheene to move no faster than the sun for two years. In this way she will cause a very high tide, a flood; five fathoms at its shallowest, it will cover the rocks on the coast. Then he will win Dorigen who has promised to be his if he makes the rocks disappear. ${ }^{37}$ Aurelius connects Lucina with Proserpina and asks that Lucina sink the rocks in Pluto's dark realm, her own dark region (FranklT $(\mathrm{F}), 1071$ 76). Here Lucina the sheene is connected with the queen of the dark realm, Proserpina.

Criseyde swears by Lucina the sheene that she will return to Troilus before the moon leaves Leo ( $T r$ IV.1590-96); she also swears by Cinthia the sheene but does not keep the oaths she swears by the bright goddesses. In The Franklin's Tale and in Troilus and Criseyde, the outcomes depend on human decisions, not on planetary intervention. When Phoebus and Lucina fail him, Aurelius seeks the help of a magician from Orleans, Criseyde decides to remain in the Greek camp, attracted by "sodeyn Diomede," and unaffected by Latona and Lucina.

\section{Diana, Proserpina}

Diana is derived from the Indo-European word for "illuminating," "lightening," "bringing light," whose stem, *diew-, "luminous," gives the variant $* d y e$, from which Latin dies, day, is derived. *Diew-yo is the suffixed feminine form of which Diana is the Latin development; *dyeu - is the stem of the masculine form from which Greek Zeus is derived. $^{38}$ This stem is also found in Dione, the name of Zeus's first

37 For a discussion of the magic and astrology in this tale, see J.S.P. Tatlock, "Astrology and Magic in Chaucer's Franklin's Tale," Anniversay Papers by Colleagues and Pupils of George Lyman Kittredge (Boston: Ginn, 1913), 339-350.

38 An asterisk indicates that the word which follows is reconstructed IndoEuropean. For a discussion of words beginning with *dieus-, see Alois Walde, Vergleichendes worterbuch der indogermaniscben sprachen, hrsg. und bearb. von Julius Pokorny (Berlin und Leipzig: Walter de Gruyter, 1930), I:772-775. For Zeus as illuminator rather than sky god, see C. Kerenyi, Zeus and Hera: Archetypal Image of Fatber, Husband, and Wife, trans. from the German by Christopher Holme (Princeton, 1975), 6-10. 
wife, at Dodona, his most ancient shrine..$^{39}$ Linguistic and mythological evidence suggest that Diana and Dione are variants of this goddess's name.

Three distinct aspects of Diana appear in Chaucer's poetry: Diana Nemorensis (of the grove), the archaic Latin goddess worshipped at Nemi as goddess of the woods, assimilated with Artemis, Mistress of Wild Things; ${ }^{40}$ Diana Lucina, goddess of childbirth; and Diana, the chaste hunter. In addition, there is Diana who rules the underworld as Proserpina.

The first portrait in The Knight's Tale shows these aspects, as the following glosses show:

Diana the chaste

Hunting and shamefast chastity;

Callisto and her son, Arcus; ${ }^{41}$

Daphne flees Apollo;

Actaeon, turned into a hart, becomes one of the hunted;

Atalanta, Diana's nymph, successfully hunts the wild boar; Meleager's father had omitted sacrifices to Diana;

Diana stands on a hart, small hounds about her feet;
$K n T$ 2051-55 [The Hunt of Virtue]

KnT 2056-59 [Punishment of nymphs who stray]

$K n T$ 2062-64 [The chaste nymph]

$K n T$ 2065-68 [The vengeful goddess]

KnT 2069-72 [Hunting and chastity; punishments for those who do not honor her]

$K n T$ 2075-76 [The hart hunt of virtue; Diana Nemorenses, Mistress of Wild Things]

39 C. Kerenyi, Zeus and Hera, 26.

40 Sir Paul Harvey, comp. and ed., The Oxford Companion to Classical Literature (Oxford: Clarendon Press, 1937; reprint 1955), 143-144. Artemis, Lady of Wild Things, was the Minoan goddess originally, not a Greek goddess (H.J. Rose, Handbook of Greek Mythology, 113).

41 Kalliste, "the fairest," is an epithet of Artemis of which Callisto is a variant. For a discussion that Artemis was once Callisto, see W.K.C. Guthrie, The Greeks and their Gods, 104, and H.J. Rose, Handbook of Greek Mytbology, 113-114. 
under her feet the waxing moon;

the statue is clothed in green; the goddess holds her bow and quiver;

she casts her eye to Pluto's dark

A woman in childbirth calls for her help
KnT 2077-78

$K n T$ 2079-80 [Diana the hunter]

KnT 2081-82 [Proserpina/Plutonia]

KnT 2083-86
[Help of the pregnant woman as Diana Lucina]

These glosses reveal a rather complex conception of the goddess, not always apparent to most critics. To William Frost, "the temple of Diana, which represents innocence and a kind of divine beneficence and is associated with Emelye, is described more naively as a collection of marvels merely; but even here the most vivid pictures are of the hounds devouring Actaeon;" Muscatine sees "the motive of misfortune and disorder...extended in ever-widening circles of reference in the description of the three temples." 42 Seen as representations either of innocence or disorder, the cruelty remains constant. The Hellenes tried to tame the wildness in the goddess by separating her functions, but they were not altogether successful. ${ }^{43}$ C. Kerenyi remarks that

Artemis...is to be found in the untamedness of young animals and equally in the terrors of childbirth. In the classical figure of this goddess, the wildness and the terror meet at a borderline; they are in equilibrium. The further we penetrate into her pre-history, the more the outlines connected with the name "Artemis" evaporate. The borderline situation widens at a border-region midway between motherhood and maidenhood, joie de vivre and lust for murder, fecundity and animality." 44

The stories of Callisto and Actaeon lie in that "border-region" of fecundity and animality; but there are the nymphs Daphne and Atalan-

42 William Frost, "An Interpretation of Chaucer's Knight's Tale," in Chaucer Criticism, Volume I: The Canterbury Tales, ed. Richard Schoeck and Jeremy Taylor (Notre Dame: 1960), 110; Charles Muscatine, Chaucer and the French Tradition: A Study in Style and Meaning (Berkeley and Los Angeles: University of California Press, 1969), 189.

43 Gilbert Murray, Five States of Greek Religion. 3rd ed. (New York: Doubleday, 1951), 56-57.

44 C. Kerenyi, "Kore," in C.G. Jung and C. Kerenyi, Essays on a Science of Mytbology (Princeton, 1959), 105. 
ta, the chaste nymph who flees from Apollo and the successful hunter of the wild boar, and the pregnant woman whom the goddess will help. These contradictions in the conception of the goddess were inherited from classical sources by medieval mythographers, who did not attempt to separate aspects or characteristics of the goddess.

To medieval mythographers, the hunt of Diana stood in stark contrast to the hunt of Venus. Robertson points out that the boar hunt and the hart hunt were motifs in the hunts of Venus and Diana; each animal may be used in either hunt. The hart, however, "enriched in meaning by associations derived from Psalm 41, the bestiaries, and the legends of St. Eustachius and St. Hubert, could also be concerned in virtuous pursuits." 45 Theseus hunts the hart under the auspices of Diana, "an iconographic action designed to reinforce the attributes of wisdom and virtue he displays elsewhere in other ways."46 The two harts in Diana's temple, as well as Atalanta's boar, vividly portray the hunt of virtue.

Emelye's prayer emphasizes the connection between the hunt of Diana and the chaste life, a connection some modern commentators do not grant her. ${ }^{47}$ Read carefully, the prayer shows not only these connections but the contradictory nature of the goddess:

O chaste goddesse of the wodes grene,

[Diana Nemorensis]

To whom bothe hevene and erthe and see is sene,

[Lucina in caelo]

[Diana in terris]

Queene of the regne of Pluto derk and lowe,

[Proserpina in inferno]

Goddesse of maydens, that myn herte hast knowe

Ful many a year, and woost what I desire,

As keepe me fro thy vengeaunce and thyn ire,

${ }^{45}$ D.W. Robertson, Jr., A Preface to Chaucer, 263.

46 Robertson, 264.

47 Chauncey Wood calls her desire to remain a virgin "a self-serving chastity," Chaucer and the Country of the Stars, 75, and says that Chaucer is satirizing her devotion to chastity. In a similar vein is Paul Thurston's evaluation of Emelye's character, Artistic Ambivalence in Chaucer's Knight's Tale (Gainesville, Fla.: University of Florida Press, 1968), 212. 
That Attheon aboughte cruelly.

Chaste goddesse, wel wostow that I

Desire to ben a mayden al my lyf,

Ne nevere wol I be no love ne wyf.

I am, thow woost, yet of thy compaignye,

A mayde, and love huntynge and venerye, ${ }^{48}$ [ the hunt of virtue]

And for to walken in the wodes wilde,

And noght to ben a wyf and be with childe. [Diana Lucina]

Noght wol I knowe compaignye of man.

Now help me, lady, sith ye may and kan,

For tho thre formes that thou hast in thee.

[Dea Triformis]

(KnT 2297-2313)

Emelye wants to remain in the hunt of virtue and not follow the hunt of Venus, of whom Palamon is a devotee. The results of the Venus hunt are vividly painted on the walls of her oratory, cruelties and suffering of love much more devastating than the suffering of chastity. The overriding emotion of Emelye's prayer is terror of adulthood. She flees, not love, but the destructive passions exemplified in Venus's oratory. In speaking of Artemis as one of the queens of heaven, Paul Friedrich writes:

Artemis projects onto the screen of myth some of the attitudes of the young unmarried sister (or daughter) who dances with other young girls....But she

48 Venerye occurs in a similar phrase in the Monk's portrait, CT, I(A), 166, "an outridere, that lovede venerye"; the Monk hunts the hare, the quarry in the hunt of Venus. Emelye's love of venerye is not to be confused with the Monk's since she wants to remain in Diana's hunt where the quarry is the hart. She flees the hunt of Venus and rejects its sensuality as depicted in Venus's oratory, $K n T$, I(A), 1,918-1,966. 
symbolizes to an exaggerated degree certain anxieties about married life, including its sexual side, that follow relocation to an unfamiliar and possibly distant family. ${ }^{49}$

Emelye's prayer reveals a very frightened young girl who gives voice to such anxieties. ${ }^{50}$ Yet she invokes the goddess of the three forms, the trinity of maiden, woman, and crone. Patron of pregnant women, $D i$ ana Lucina, is one of the aspects of the goddess. Emelye knows that fate is against her. She asks that if it be her destiny to marry one of the knights, may her goddess send her the lover who loves her most. Her prayer is answered in a roundabout way, for events turn out in her favor. Arcite dies and a period of some years pass as the court mourns. Thus Theseus is prevented from marrying her off summarily, as seems to be his intention. ${ }^{51}$

The last aspect of the goddess is Proserpina. Proserpina (the fearful one) is the Latin development of Greek Persephone, derived from phero and phonos, "She who brings destruction," 52 and is the name of the queen of the underworld. Herodotus and Pausanias mention a play

49 Paul Friedrich, The Meaning of Apbrodite (Chicago: Chicago University Press, 1978), 83.

50 Similar fears are expressed most poignantly in a poem by a woman troubadour, whose refrain is: Essems maritz mi par trop angoissos, "It's too anguishing to be a wife," in Meg Bogin, The Women Troubadours (New York: W.W. Norton, 1976), 144-145. For frequency of births for all classes of women in the Middle Ages, see David Herlihy, "The Natural History of Women," Natural History 87 (1978): 56-67; for abortion, abandonment, and infanticide, see Emily Coleman, "Infanticide in the early Middle Ages," in Women in Medieval Society, ed. Susan Mosher Stuard (Philadelphia: University of Pennsylvania Press, 1976), 47-70.

51 Hope Phyllis Weissman points out that, unlike Dame Nature in The Parlement of Foules, who takes the former eagle's desires into account and asks the suitor-eagles to wait a year, Theseus never asks Emelye what her wishes are although he knows that she "woot namore of al this hoote fare" than a cuckoo or a hare (KnT. I(A), 1,809-10), "Antifeminism and Chaucer's Characterizations of Women," in Geoffrey Chaucer, ed. George D. Economou (New York: McGrawHill, 1975), 100-101. Weissman does not point out that fate intervenes. For a brilliant analysis of this tale, see Charles Muscatine, "Form, Texture and Meaning in Chaucer's Knight's Tale," PMLA 65 (1950): 911-929.

52 Robert Graves, The Greek Myths. 2 vols. (Baltimore, Md.: Penguin, 1955), $1: 92-93, \mathrm{nn} .1-2$. 
by Aeschylus (now lost) in which Artemis is the daughter of Demeter, hence Persephone. ${ }^{53}$ The assimilation was thus known in classical times. Martianus Capella says that the sublunar air is in the power of Pluto and here Luna is called Proserpina. ${ }^{54}$ The connection between Lucina and Proserpina occurs in The Franklin's Tale (discussed above). Elsewhere, Proserpina is "quene of the derke pyne," (HF III.1511-12), and Troilus expects to complain eternally in Proserpina's dark realm if Criseyde leaves him ( $\operatorname{Tr}$ IV.470-476). Proserpina is "la regina dell" eterno pianto," in Inferno IX.44, and mistress of the Erinyes-Alecto, Megaera, and Tisiphone. ${ }^{5}$ In both Chaucer and Dante she is the fearful one. She is called Proserpina ferox in De Raptu Proserpinae, I.15, and the gloss on a medieval manuscript explains that ferox does not refer to her status when she was ravished but to what she became as queen of Hades. ${ }^{56}$ She is associated with the darkness of the underworld in all of Chaucer's references except in The Merchant's Tale where she is associated with the bright day and called the queen of "fayerye." 77 Marcia A. Dalbey agrees with G.G. Sedgewick's assessment that as King and Queen of "fayerye" Pluto and Proserpina are re-

53 Herodotus, The Histories, II.158, trans. Aubrey de Selincourt (Baltimore, Md.: Penguin, 1954), 165 ; Pausanias, Descriptions of Greece, VIII.37.6, trans. Frazer, $1: 422$.

54 Martianus Capella, The Marriage of Pbilology and Mercury, Book 2, [160], trans. Stahl and Johnson, 54.

55 For Dante's influence on Chaucer's conception of Proserpina and the Furies, see John L. Lowes, "Chaucer and Dante," Modern Pbilology 14 (1916-17): 142148.

56 Mortimer J. Donovan, "Chaucer's January and May: Counterparts in Claudian," in Chaucerian Problems and Perspectives: Essays Presented to Paul E. Beichner, C.S.C., ed. Edward Vasta and Zacharias P. Thundy (Notre Dame: 1979), 61. For the Claudian Chaucer knew, an adition of De Raptu Proserpinae in Liber Catonianus, see Robert A. Pratt, "Chaucer's Claudian," Speculum 22 (1947): 419-429.

57 On this episode, see Mortimer J. Donovan, "The Image of Pluto and Proserpine in The Merchant's Tale," Pbilological Quarterly 36 (1957): 49-60; Marcia A. Dalbey, "The Devil in the Garden," Neuphilologische Mitteilungen 75 (1974): 408-415; Karl P. Wentersdorf, "Theme and Structure in The Merchant's Tale: The Function of the Pluto Episode," PMLA 80 (1965): 522-527. 
duced to the little mean dark people of folklore. "Small, mean, and petty, they engage in a domestic quarrel which strips them of any glamour or sensuous appeal they might otherwise have had." 58 It is true that Pluto and Proserpina quarrel, but they are not dark little people. They are even happy sometimes; they dance and disport themselves about the well in January's garden as soon as it is finished. Not even Priapus could describe

The beautee of the gardyn and the welle,

That stood under a laurer alwey grene.

Ful ofte tyme he Pluto and his queene,

Proserpina, and al hire fayerye,

Disporten hem and maken melodye

About that welle, and daunced, as men tolde. (IV.2036-2041)

The passage shows the influence of Sir Orfeo, where the king of "fayerye" carries off Dame Heurodis to the underworld; Sir Orfee later sees them dancing off in the distance accompanied by drums and trumpets. ${ }^{59}$ The instruments are absent from Chaucer's description, but "maken melodye" implies that music accompanies the dance. In this tale, the gods enter the human world and deliberately influence the outcome of the plot. Pluto, who has acquired his wife by rape, decides to give January his sight; Proserpina, the irritable and abused wife, decides to give May her answer.

On the fateful day, as January and May go into the garden,

Bright was the day, and blew the firmament;

Phebus hath of gold his stremes doun ysent,

To gladen every flour with his warmnesse.

He was that tyme in Geminis, as I gesse,

But litel fro his declynacion

Of Cancer, Jovis exaltacion.

And so bifel, that brighte morwe-tyde,

That in that gardyn, in the ferther syde,

58 Marcia A. Dalbey, "The Devil in the Garden," 414.

59 Sir Orfeo, 297-302, ed. A.J. Bliss (London: Oxford University Press, 1954), 27. See also, Laura Hibbard Loomis, "Chaucer and the Breton Lays of the Auchinleck MS.," Studies in Pbilology 38 (1941): 24-29, for The Merchant's Tale; and John Block Friedman, "Eurydice, Heurodis, and the Noon Day Demon," Speculum 41 (1966): 22-29. 
Pluto, that is kyng of Fayerye,

And many a lady in his compaignye,

Folwynge his wyf, the queen Proserpyna,

Which that he ravysshed out of Ethna

Whil that she gadered floures in the mede-

In Claudyan ye may the stories rede,

How in his grisely carte he hire fette-

This kyng of Fairye thanne adoun hym sette

Upon a bench of turves, fressh and grene. (IV.2219-2235)

The brightness of the day is emphasized in line after line in this passage; it is, after all, about June $12 .{ }^{60}$ In the quarrel which ensues, Proserpina appears as bitch goddess as she takes May's part. Both wives are in similar situation; young women married to old husbands who are distasteful to them, Proserpina abducted by Pluto and May hastily married to January. Mortimer J. Donovan has remarked that May's "display of affection after marriage is so forced as to make her appear the object of a raptus as real as Proserpine's."61

Proserpina is the only aspect of the moon goddess presented in a dramatic vignette; she is the most powerful of the moon goddesses in Chaucer's work for it is her action which determines the outcome of the drama in the garden. The other goddesses, though vividly presented, do not determine the action of the plot. Cynthia does not influence Criseyde; Latona cannot help Troilus; and Lucina does not make the rocks disappear for Aurelius. Diana tells Emelye that the "high gods" have decided that she must marry, thus deliberately removing herself from action of the poem's denouement. Proserpina, however, gives May her answer, enabling her to checkmate January. The bright goddesses-"Cinthia the sheene," "Latona the clere," and "Lucina the sheene"-seem remote and ineffectual; the dark goddess, the "queene of fayerye" as she reminds Pluto, who appears in the bright world in the middle of summer, helps May to deceive her husband. In the world of the moon goddesses, the power of darkness seems stronger than the power of light, and it is the fearful one who is most effective.

Each name, then, denotes a particular image of the moon goddess,

60 Robinson, “Explanatory Notes,” 716.

61 Mortimer J. Donovan, "The Image of Pluto and Proserpine in The Merchant's Tale," 52. 
sometimes complementary as in Diana the hunter and Cynthia the charioteer, sometimes contradictory as in Diana the chaste, who punishes pregnant nymphs, and Diana Lucina, who helps pregnant women. The images and aspects are linked unmistakably, as in the Diana-LucinaProserpina triad in The Knight's Tale and in Lucina-Proserpina in The Franklin's Tale, with several others suggested though unnamed, for example, Diana Nemorensis. One might wish for more precise categories and more consistent naming, but such precision and consistency clearly did not occur to medieval mythographers or to Chaucer. Chaucer's immediate sources may have been visual or textual or a combination of both, ${ }^{62}$ but whatever the source, his unique application enriches the narrative, suggesting always the precariousness and instability of human aspiration and desire.

Brooklyn College, CUNY

New York

62 For the relationship between image and text in mythological handbooks, see Erwin Panofsky, Renaissance and Renascences, 78-80, n.2; his chart shows relationships between texts for descriptions of the planetary gods, 81. Particularly instructive is V.A. Kolve, "Chaucer and the Visual Arts," in Geoffrey Chaucer, ed. Derek Brewer. Writers and their Backgrounds. (Columbus, Ohio: Ohio University Press, 1975), 290-320. 